\title{
Evaluation of the Content of Free Amino Acids in Tobacco by a New Liquid Chromatography-Tandem Mass Spectrometry Technique*
}

\author{
by \\ Serban C. Moldoveanu ${ }^{1}$, Jeff Zhu ${ }^{2}$, and Wayne A. Scott ${ }^{l}$ \\ ${ }^{1}$ R.J. Reynolds Tobacco Co., 950 Reynolds Blvd., Winston-Salem, NC, 27105, USA \\ ${ }^{2}$ Eurofins Lancaster Laboratories, Inc., 950 Reynolds Blvd., Winston-Salem, NC, 27105, USA
}

\section{SUMMARY}

The present study describes a reliable technique for the analysis of free amino acids in tobacco leaf. The levels of amino acids in tobacco are important since they are related to both tobacco quality and the potential generation in cigarette smoke of toxicants having amino acid precursors. Other techniques used in the past for amino acid analysis have various shortcomings that were avoided in the present method. The new method uses HPLC separation and a tandem mass spectrometer for detection with no derivatization step as sample preparation. The separation has been obtained using ion pair HPLC on a reversed phase column that offers excellent chromatographic resolution. The MS/MS detection procedure offers very good sensitivity and positive identification of the analytes. The procedure was fully validated and can be used for the analysis of 24 amino acids. It was applied for the quantitation of amino acids from 16 types of tobacco including flue-cured and Burley, some domestic and some not grown in the USA, two types of Oriental tobacco, and from tobacco of a 3R4F Kentucky reference and a common commercial cigarette. It was shown that the analysis provides useful information regarding the amino acid level variation between tobacco types, between tobacco stalk positions, and between the growing locations of different tobaccos. [Beitr. Tabakforsch. Int. 26 (2015) 334-343]

\section{ZUSAMMENFASSUNG}

Die vorliegende Studie beschreibt ein zuverlässiges Verfahren zur Analyse der freien Aminosäuren in Tabakblättern. Dabei ist der Gehalt an Aminosäuren im Tabak wichtig, da er sowohl mit der Qualität des Tabaks als auch mit der möglichen Entstehung von Giftstoffen im Zigarettenrauch, deren Vorläufer Aminosäuren sind, im Zusammenhang steht. Andere in der Vergangenheit eingesetzte Verfahren zur Analyse von Aminosäuren haben verschiedene Nachteile, die in dem vorliegenden Verfahren umgangen wurden. Bei der neuen Methode kommen die HPLCTrennung und ein Tandem-Massenspektrometer ohne Derivatisierungsschritt zur Probenvorbereitung für den Nachweis zum Einsatz. Die Trennung wurde mittels Ionenpaar-HPLC an einer Umkehrphasensäule mit hervorragender chromatographischer Auflösung erreicht. Das MS/MS-Nachweisverfahren bietet eine sehr gute Sensitivität und positive Identifizierung der Analyten. Das Verfahren wurde vollständig validiert und kann für die Analyse von 24 Aminosäuren verwendet werden. Es wurde für die Quantifizierung von Aminosäuren von 16 Tabaksorten eingesetzt, darunter Flue-cured und Burley, einige in den USA einheimische und einige nicht in den USA wachsende Sorten, zwei Arten von Orienttabak sowie Tabak einer Kentucky-Referenzzigarette 3R4F und einer handelsüblichen Zigarette. Dabei wurde gezeigt, dass die Analyse nützliche Informationen zur Variation des Aminosäuregehalts zwischen Tabaksorten, Tabakstängel-Positionen und den Anbaugebieten verschiedener Tabaksorten ergibt. [Beitr. Tabakforsch. Int. 26 (2015) 334-343] 


\section{RESUME}

La présente étude décrit une technique fiable d'analyse des acides aminés libres présents dans la feuille de tabac. Les teneurs en acides aminés sont d'importance dans le tabac puisqu'elles sont liées tant à la qualité du tabac qu'à la production potentielle, dans la fumée de tabac, de substances toxiques ayant des acides aminés précurseurs. D'autres techniques utilisées par le passé lors de l'analyse des acides aminés souffrent de diverses lacunes que la présente méthode évite. Cette nouvelle approche fait appel à la séparation en CLHP ainsi qu'à un spectromètre de masse en tandem (MS/MS) pour la détection sans passer par l'étape de dérivatisation pour préparer l'échantillon. La séparation est obtenue grâce à une colonne CLHP en phase inverse avec appariement d'ions, qui offre une excellente résolution chromatographique. La procédure de détection MS/MS offre une très bonne sensibilité et une identification positive des analytes. La procédure est pleinement validée et peut être utilisée pour l'analyse de 24 acides aminés. Elle a été appliquée à l'analyse chimique quantitative d'acides aminés provenant de 16 types de tabac, notamment du tabac jaune et du tabac Burley, certains tabacs cultivés aux USA et d'autres cultivés ailleurs, deux types de tabac d'Orient, du tabac de cigarettes de référence Kentucky 3R4F et une cigarette ordinaire vendue dans le commerce. Il a été démontré que l'analyse apporte des informations utiles quant à la variation de la teneur en acides aminés selon le type de tabac, la position des tiges de tabac et le lieu de culture des différents tabacs. [Beitr. Tabakforsch. Int. 26 (2015) 334-343]

\section{KEYWORDS}

Amino acids, tobacco, LC-MS/MS, HPLC-fluorescence

\section{INTRODUCTION}

The level of amino acids in tobacco is an important parameter for leaf characterization, both related to tobacco quality (1-3) and also related to the generation of toxicants in cigarette smoke (4-5). The smoke sensory properties are affected by the amino acids either directly, or through the further formation of Amadori compounds (1). Among the main toxicants having amino acids as a precursor are hydrogen cyanide (6), acrylamide $(7,8)$, and heterocyclic amines (6). For these reasons, research regarding amino acid analysis in tobacco leaf has been active over a long period of time $(9,10)$. Also, a considerable number of analytical methods are reported in the literature for the analysis of either free amino acids $(12,13)$ or of amino acids in proteins after protein hydrolysis (13). Analysis of amino acids is a challenging subject since the GC (GC-MS) analysis is not possible without derivatization, and for HPLC, the conventional ultra violet (UV) or fluorescence detection of underivatized amino acids is not applicable. The amino acid molecules do not contain chromophores or fluorophores (except for a few amino acids containing aromatic groups that have strong UV absorption) and their detection cannot be done by UV or fluorescence. For this reason HPLC is also frequently performed after derivatization. Among the most common procedures of derivatization for HPLC analysis is the reaction with $o$-phthalaldehyde (OPA) for amino acids containing a primary amino group and with fluorenylmethyl chloroformate (FMOC) for amino acids containing a secondary amino group $(14,15)$. However, derivatization adds an important source of errors since it implies an additional processing step for the samples, and typically the derivatized amino acids are not stable in time. For this reason, present work had the goal of developing an analytical technique for amino acid analysis without involving derivatization. An additional problem with the analysis of amino acids without derivatization is related with their separation. Hydrophilic interaction chromatography (HILIC) type columns and ion-exchange columns can be used for free amino acid separation, but the peak resolution in these cases is typically lower than that for reversed phase (RP) $(16,17)$. For allowing a separation of amino acids on a $\mathrm{C} 18$ column, the use of ion pairing was considered the best solution. The present study describes a new method for free amino acid analysis by a novel HPLC separation using ion pairing and a reversed-phase (RP) chromatographic column, followed by mass spectrometric detection (MS/MS detection in multiple reaction monitoring, MRM mode). The method offers a number of advantages such as no need for derivatization, excellent peak shape in the chromatogram, good separation, and positive identification of each amino acid in the tobacco complex matrix.

\section{EXPERIMENTAL}

\section{Materials}

Various amino acids including asparagine, glutamine, tryptophan and 3,3,3- $\mathrm{d}_{3}$-alanine, trifluoroacetic acid, hydrochloric acid (37\%), and acetonitrile (CHROMASOLV $^{\circledR}$ Plus) were purchased from Sigma-Aldrich (St. Louis, MO, USA). Heptafluorobutyric acid was purchased from TCI America (Portland, OR, USA). Pure water (18.2 $\mathrm{m} \Omega / \mathrm{cm}$ ) from a Barnsted Nanopure unit (Thermo Scientific, Waltham, MA, USA) was used for the preparation of solutions. The "Amino Acid Standard H" with $2.5 \mu \mathrm{mol} / \mathrm{mL}$ concentration of several amino acids was purchased from Thermo Fisher Scientific (Rockford, IL, USA). Autovial $0.45 \mu \mathrm{m}$ pore PVDF filters (Whatman, Clifton, $\mathrm{NJ}$ ) were used for sample filtration.

\section{Instrumentation}

The extraction of the samples was performed on a wrist action shaker (Burrell Co., Pittsburgh, PA, USA). The separation was performed on an Agilent 1200 HPLC binary system (Agilent Technologies Inc., Wilmington, DE, USA). The HPLC system consisted of a binary pump, an autosampler with cooling capability, and a column thermostatted compartment. The chromatographic column was a Dionex Acclaim ${ }^{\mathrm{TM}}$ RSLC Polar Advantage II, $2.1 \times 250 \mathrm{~mm}$ with $2.2 \mu \mathrm{m}$ particles (from Thermo Scientific). This is a silica based $\mathrm{C} 18$ column with a patented bonding chemistry that provides enhanced hydrolytic stability from $\mathrm{pH} 1.5-10$ 
and allows resolution of a wide variety of polar and nonpolar analytes. The detection of the analytes was performed using an API-5000 triple quadrupole mass spectrometer (AB Sciex, Framingham, MA, USA).

\section{Extraction of amino acids from tobacco leaf}

About $5 \mathrm{~g}$ of tobacco (cut filler) was finely ground using a coffee grinder. The samples were kept before analysis for $48 \mathrm{~h}$ in a conditioned room at $21 \pm 0.5{ }^{\circ} \mathrm{C}$ and $60 \pm 2 \%$ relative humidity. This procedure brings samples to a common value for water activity. The amino acids were extracted using an aqueous solution of $0.1 \mathrm{M} \mathrm{HCl}$. The solution also contained $25 \mu \mathrm{mol} / \mathrm{L}(0.2286 \mu \mathrm{g} / \mathrm{mL}) \mathrm{d}_{3}$-alanine as an internal standard. Another internal standard used optionally was $25 \mu \mathrm{mol} / \mathrm{L}$ phenylglycine $(0.3807 \mu \mathrm{g} / \mathrm{mL})$. Plenylglycine is not present in tobacco. For the extraction, $50 \mathrm{mg}$ of finely ground tobacco (conditioned as previously indicated) were precisely weighed $( \pm 0.1 \mathrm{mg})$ into a $50 \mathrm{~mL}$ vial. To this tobacco, $25 \mathrm{~mL}$ extracting solution was added. The vial with the tobacco and the extracting solution was then subject to mechanical agitation for $30 \mathrm{~min}$, e.g., on a wrist action shaker. A portion of the resulting extract was filtered through a $0.45 \mu \mathrm{m}$ PVDF filter. The samples were stable for at least $48 \mathrm{~h}$ at $10{ }^{\circ} \mathrm{C}$. An alternative extraction procedure uses only $5 \mathrm{~mL}$ extracting solution and $50 \mathrm{mg}$ tobacco in a $20 \mathrm{~mL}$ vial and mechanical agitation. This solution can be used for the analysis of amino acids in tobacco, except for proline. Proline is at a high level in flue-cured and Oriental tobaccos, and the proline peak in the chromatogram is overloaded and not possible to quantitate. However, a modification in the MS/MS acquisition conditions (decrease of the collision cell potential for proline measurement from $15 \mathrm{~V}$ to $5 \mathrm{~V}$ ) allowed the use of more concentrated solution for analysis.

\section{HPLC separation}

The amino acids were separated using ion pairing on the Acclaim $^{\mathrm{TM}}$ RSLC Polar Advantage II column $2.1 \times 250 \mathrm{~mm}$ with $2.2 \mu \mathrm{m}$ particles. The samples were kept in the autosampler at $10{ }^{\circ} \mathrm{C}$. The separation was performed at a flow rate of $0.2 \mathrm{~mL} / \mathrm{min}$ using gradient. Solution A was water containing $1 \%$ acetonitrile, $0.5 \%$ heptafluorobutyric acid, $0.02 \%$ trifluoroacetic acid (by volume), and solution B was $0.1 \%$ trifluoroacetic acid in acetonitrile (by volume). The gradient conditions started with $0 \%$ solution $\mathrm{B}$, linear increase to $5 \%$ solution $\mathrm{B}$ from $5 \mathrm{~min}$ to $7 \mathrm{~min}$, linear increase to $60 \% \mathrm{~B}$ from $7 \mathrm{~min}$ to $18 \mathrm{~min}$ and kept at $60 \% \mathrm{~B}$ for 3 more min. The column is reset to $5 \% \mathrm{~B}$ and then to $0 \% \mathrm{~B}$. An equilibration time of $4 \mathrm{~min}$ was necessary before each run. The rather long equilibration time was necessary in the separation since the flow was relatively low, and the column is $250 \mathrm{~mm}$ long. The column temperature was kept at $20^{\circ} \mathrm{C}$. The injection volume was $3 \mu \mathrm{L}$. Needle wash with methanol was performed before every injection.

\section{Mass spectral detection}

The detection of the analytes was performed using a triple quadrupole mass spectrometer, working in multiple reaction monitoring (MRM) mode. The parameters for the detection
Table 1. Parameters for the MS detection.

\begin{tabular}{lcc}
\hline Parameter & Value & Units \\
\hline Polarity & positive & - \\
Collision gas (CAD) & 5 & $\mathrm{~mL} / \mathrm{min}$ \\
Curtain gas (CUR) & 10 & $\mathrm{~mL} / \mathrm{min}$ \\
lon source gas 1 (GS1) & 55 & $\mathrm{~mL} / \mathrm{min}$ \\
lon source gas 2 (GS2) & 55 & $\mathrm{~mL} / \mathrm{min}$ \\
lon spray voltage (IS) & 5500 & $\mathrm{~V}$ \\
Temperature (TEM) & 450 & ${ }^{\circ} \mathrm{C}$ \\
Interface heater (ihe) & off & - \\
Declustering potential (DP) & 60.0 & $\mathrm{~V}$ \\
Entrance potential (EP) & 4.0 & $\mathrm{~V}$ \\
Collision energy (CE) for all & 15.0 & $\mathrm{eV}$ \\
$\quad$ amino acids & & \\
Collision energy (CE) for proline when & & \\
$\quad$ using extraction of 50 mg tobacco in & 5.0 & $\mathrm{eV}$ \\
$\quad 5$ mL solution & & \\
Collision cell exit potential (CXP) & 13.0 & $\mathrm{~V}$ \\
Acquisition time per ion & 50 & $\mathrm{~ms}$ \\
Total acquisition time & 25 & $\mathrm{~min}$ \\
& & \\
\hline
\end{tabular}

Table 2. Transitions and retention times for the amino acids.

\begin{tabular}{|c|c|c|c|c|c|}
\hline No. & Amino Acid & Abbr. & $\begin{array}{l}\text { Precursor } \\
\text { ion }\end{array}$ & $\begin{array}{l}\text { Product } \\
\text { ion }\end{array}$ & $\begin{array}{l}\text { Retention } \\
\text { time (min) }\end{array}$ \\
\hline 1 & Valine & Val & 72 & 55 & 17.21 \\
\hline 2 & Glycine & Gly & 76 & 30 & 4.53 \\
\hline 3 & Alanine & Ala & 90 & 44 & 5.52 \\
\hline 4 & Sarcosine & Sar & 90 & 30 & 5.97 \\
\hline 5 & d3-Alanine & d3-Ala & 93 & 47 & 5.48 \\
\hline 6 & Serine & Ser & 106 & 88 & 4.50 \\
\hline 7 & Proline & Pro & 116 & 70 & 8.52 \\
\hline 8 & Threonine & Thr & 120 & 56 & 5.19 \\
\hline 9 & Cysteine & Cys & 122 & 87 & 12.01 \\
\hline 10 & Isoleucine & Ile & 132 & 86 & 19.93 \\
\hline 11 & Leucine & Leu & 132 & 86 & 20.25 \\
\hline 12 & Hydroxyproline & Hyp & 132 & 86 & 4.63 \\
\hline 13 & Asparagine & Asn & 133 & 74 & 4.46 \\
\hline 14 & Ornitine & Orn & 133 & 70 & 19.90 \\
\hline 15 & Aspartic acid & Asa & 134 & 88 & 4.88 \\
\hline 16 & Glutamine & GIn & 147 & 101 & 4.81 \\
\hline 17 & Lysine & Lys & 147 & 84 & 16.17 \\
\hline 18 & Glutamic acid & Glu & 148 & 84 & 5.77 \\
\hline 19 & Methionine & Met & 150 & 133 & 18.19 \\
\hline 20 & Phenylglycine & Phg & 152 & 106 & 19.20 \\
\hline 21 & Arginine & Arg & 175 & 70 & 19.50 \\
\hline 22 & Histidine & His & 156 & 110 & 17.60 \\
\hline 23 & Phenylalanine & Phe & 166 & 120 & 21.09 \\
\hline 24 & Citruline & Cit & 176 & 70 & 19.25 \\
\hline 25 & Tyrosine & Tyr & 182 & 165 & 19.56 \\
\hline 26 & Tryptophan & Trp & 205 & 188 & 22.18 \\
\hline
\end{tabular}

of amino acids are given in Table 1. The transitions for MRM mode of analysis (mass of precursor ion and product ion), and the retention time for 26 amino acids that were evaluated in this study are given in Table 2. A typical chromatogram obtained for a solution of standards containing $25 \mu \mathrm{mol} / \mathrm{L}$ standards is shown in Figure 1 . The separation of the amino acids was good, and since each amino acid has a specific transition, some overlapping of the chromatographic peaks poses no problem. 


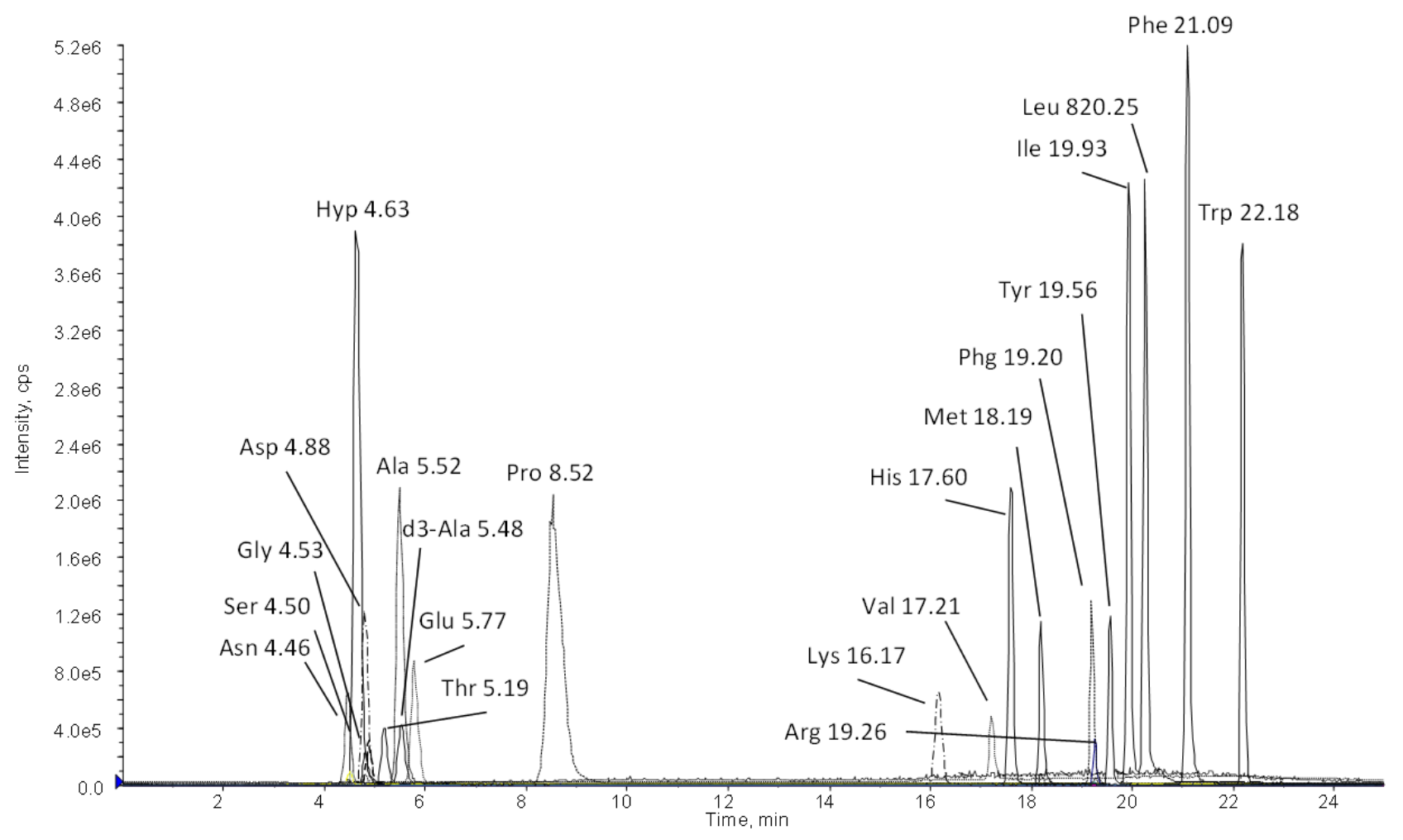

Figure 1. Chromatogram for a mixture of amino acids containing $25 \mu \mathrm{mol} / \mathrm{L}$ standards.

\section{Quantitation}

For the quantitation of the amino acids, five standards were prepared, containing all the amino acids at concentrations in the range 0.25 to $50 \mu \mathrm{mol} / \mathrm{L}$ of each amino acid. From the list of amino acids indicated in Table 2, the standards for citruline, ornithine, and sarcosine were absent $\left(\mathrm{d}_{3}\right.$ alanine and phenylglycine were added as internal standards). The calibration for some amino acids was linear, but for other amino acids a quadratic calibration was necessary. The equations of the form

$$
Y=a X^{2}+b X
$$

where $\mathrm{Y}$ is the concentration of the amino acid in $\mathrm{mg} / \mathrm{mL}$ and $\mathrm{X}$ is the peak area for the calibration lines are listed in Table 3. The $\mathrm{R}^{2}$ of the trendlines are also shown in the table (the equations of trendlines and $\mathrm{R}^{2}$ values were obtained using Microsoft Excel capabilities). Most $\mathrm{R}^{2}$ values in Table 3 are higher than 0.99 . Only isoleucine showed $\mathrm{R}^{2}=0.97580$, leucine showed $\mathrm{R}^{2}=0.98168$ and phenylalanine (including a high concentration point) showed $\mathrm{R}^{2}=0.94280$. The calibration curves were obtained by plotting the levels of standards versus the corresponding peak areas for each analyte without normalization by an internal standard. The internal standards have been used only for verifying the reproducibility of the chromatograms. The two internal standards showed small variations not larger than $\pm 5 \%$. Since no sample preparation (except for extraction) has been applied to the sample, the internal standard was just one other analyte with its own variability, and it was not desirable to impose its variability to all other compounds. In addition to the equations of the calibrations, Table 3 also shows the signal to noise $\mathrm{S} / \mathrm{N}$ of the peaks of individual amino acids for their lowest standard $(0.25 \mu \mathrm{mol} / \mathrm{L})$. As shown in Table 3 , the $\mathrm{R}^{2}$ values for the calibrations are very good, except for phenylalanine where the range was limited between $0.25 \mu \mathrm{mol} / \mathrm{L}$ and $25 \mu \mathrm{mol} / \mathrm{L}$ for achieving better correlation.

\section{Validation}

Several aspects related to the validation of the LC-MS/MS method were evaluated following recommendation provided in the literature (18). The selectivity of the method is very good, the combination of HPLC separation and $\mathrm{MS} / \mathrm{MS}$ detection being sufficient for the elimination of interferences.

The precision of the method is also very good, as further shown for a set of tobaccos analyzed by this technique (see section Results and Discussion). The analysis in triplicate of 16 tobacco types for 21 amino acids, led to RSD\% typically below $5 \%$ and for some amino acids at low levels to RSD between $5 \%$ and $10 \%$. From 336 different averages (different samples and different amino acids) one RSD\% value was $10.3 \%$ for isoleucine in a flue-cured sample, and one was $10.6 \%$ (for cysteine in a Burley sample).

The evaluation of linearity in the LC-MS/MS method showed that a number of amino acids generate quadratic responses in the technique and only quadratic curves displayed $\mathrm{R}^{2}$ values higher than 0.90 as shown in Table 3 . However, all amino acids used for the calibrations were at equal concentration. This is not the case for tobacco samples that may contain large levels of asparagine, aspartic acid, and proline, and much lower levels of other amino acids. In addition to that, the MS/MS response for different analytes is very different and may differ for the 
Table 3. Equations for the calibration curves. $Y=a X^{2}+b X$, where $Y$ is the concentration of the amino acid in $\mathrm{mg} / \mathrm{mL}$ and $X$ is the peak area. The $\mathrm{R}^{2}$ of the trendlines for the calibrations are also shown, as well as the signal to noise $\mathrm{S} / \mathrm{N}$ for the lowest standard (0.25 $\left.\mu \mathrm{mol} / \mathrm{mL}\right)$.

\begin{tabular}{|c|c|c|c|c|c|}
\hline No. & Amino acid & $a$ & $\mathrm{~b}$ & $\mathrm{R}^{2}$ & $\mathrm{~S} / \mathrm{N}$ \\
\hline 1 & Alanine & $-^{a}$ & 5.7399 e-8 & 0.99129 & 23.8 \\
\hline 2 & Arginine & - & $1.8576 \mathrm{e}-7$ & 0.99594 & 11.2 \\
\hline 3 & Asparagine & $1.2443 \mathrm{e}-15$ & $5.6202 \mathrm{e}-8$ & 0.99940 & 94.4 \\
\hline 4 & Aspartic acid & $2.1454 \mathrm{e}-15$ & $7.0439 \mathrm{e}-8$ & 0.99870 & 152.4 \\
\hline 5 & Citruline & - & - & - & 11.5 \\
\hline 6 & Cysteine & - & $1.2308 \mathrm{e}-5$ & 0.99727 & 7.1 \\
\hline 7 & d3-Alanine & - & - & - & 一 \\
\hline 8 & Glutamic acid & - & $4.0667 \mathrm{e}-8$ & 0.99743 & 137.3 \\
\hline 9 & Glutamine & $1.5253 \mathrm{e}-14$ & 1.4082 e-7 & 0.99838 & 81.8 \\
\hline 10 & Glycine & $1.8604 \mathrm{e}-13$ & 3.5670 e-7 & 0.99552 & 16.2 \\
\hline 11 & Histidine & $2.6872 \mathrm{e}-16$ & $1.5928 \mathrm{e}-8$ & 0.99625 & 338.6 \\
\hline 12 & Hydroxyproline & 1.7397 e-16 & 4.1807 e-9 & 0.99742 & 590.8 \\
\hline 13 & Isoleucine & 3.7915 e-16 & 2.4138 e-9 & 0.97580 & 552.6 \\
\hline 14 & Leucine & 3.7538 e-16 & 1.0648 e-8 & 0.98168 & 458.5 \\
\hline 15 & Lysine & - & 4.5148 e-8 & 0.99911 & 106.8 \\
\hline 16 & Methionine & - & 3.3102 e-8 & 0.99330 & 1435.1 \\
\hline 17 & Ornitine & - & - & - & 一 \\
\hline 18 & Phenylalanine & 5.3655 e-16 & -7.2185 e-9 & 0.94280 & 一 \\
\hline $18 a$ & Phenylalanine (low range) & $2.9297 \mathrm{e}-16$ & -7.3718 e-10 & 0.99288 & 609 \\
\hline 19 & Phenylglycine & - & - & - & - \\
\hline 20 & Proline & $1.7842 \mathrm{e}-17$ & 5.9270 e-9 & 0.99883 & 128.1 \\
\hline $20 a$ & Proline (low range) & - & $1.4997 \mathrm{e}-8$ & 0.99784 & - \\
\hline 21 & Sarcosine & - & - & - & 一 \\
\hline 22 & Serine & 2.6751 e-13 & 4.3417 e-9 & 0.99890 & 11.1 \\
\hline 23 & Threonine & - & 9.9900 e-8 & 0.99881 & 79.1 \\
\hline 24 & Tryptophan & 2.8858 e-16 & 3.7112 e-9 & 0.99055 & 2611.1 \\
\hline 25 & Tyrosine & 7.8556 e-16 & $4.2847 \mathrm{e}-8$ & 0.99840 & 477.4 \\
\hline 26 & Valine & - & 6.6510 e-8 & 0.99600 & 14.9 \\
\hline
\end{tabular}

a - indicates not applicable, since these amino acids were not quantitated.

same analyte concentration, by two orders of magnitude. For these reasons, an appropriate choice of concentration for the standards may further improve $\mathrm{R}^{2}$ values for the calibrations.

The extraction with $0.1 \mathrm{~N} \mathrm{HCl}$ for the free amino acids has been demonstrated in other methods for amino acid analysis (14) and data from long experience in the laboratory indicated that 30 min extraction time are sufficient for the complete extraction of many soluble analytes. For this reason only limited experiments were performed to evaluate extraction efficiency, which was performed in the study only for one tobacco type (lower stalk flue-cured). The variation in the level of three amino acids (asparagine, aspartic acid, and proline) as a function of extraction time is shown in Figure 2 (triplicate measurements). As expected, a time of extraction of about 30 min was sufficient for a complete extraction for the analyzed amino acids. A longer-than-one-hour extraction time indicated a slight decrease in the measured level of asparagine and an increase in aspartic acid, very likely due to hydrolysis of a small proportion of asparagine to aspartic acid. The same effect was noticed for the glutamine/glutamic acid pair. The recovery of the analytical procedure was also evaluated in the study. The $\%$ recovery of the amino acids for a fluecured tobacco sample was evaluated using two spiking levels. For this purpose, three samples of $50 \mathrm{mg}$ tobacco were analyzed in duplicate. The first sample did not have any addition of amino acids. The second sample was extracted with $45 \mathrm{~mL}$ extracting solution, and $5 \mathrm{~mL}$ of a standard containing $2.5 \mu \mathrm{mol} / \mathrm{L}$ of each amino acid was added. The third sample was extracted with $45 \mathrm{~mL}$ extracting solution and $5 \mathrm{~mL}$ of a standard containing $25 \mu \mathrm{mol} / \mathrm{L}$ of each amino acid was added. The three extracts were analyzed and the extraction efficiency was calculated as the ratio of analyzed amino acid level vs.

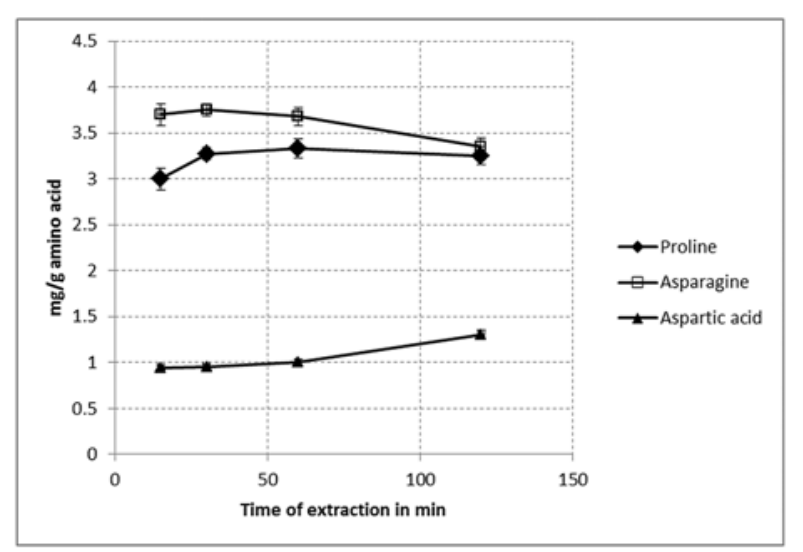

Figure 2. Variation with extraction time for the measured level of three amino acids in a flue-cured tobacco (triplicate measurement). 
Table 4. Recovery (\%) for amino acids spiked at two levels on a cured tobacco sample.

\begin{tabular}{l|rr}
\hline \multirow{2}{*}{ Compound } & \multicolumn{2}{|c}{ Tobacco A } \\
\cline { 2 - 3 } & Low spiked & High spiked \\
\hline Alanine & 105.7 & 107.7 \\
Arginine & 100.0 & 107.2 \\
Asparagine & 82.8 & 101.1 \\
Aspartic acid & 96.8 & 96.3 \\
Glutamic acid & 108.9 & 100.5 \\
Glutamine & 103.4 & 111.4 \\
Glycine & 86.8 & 86.0 \\
Histidine & 101.2 & 108.0 \\
Isoleucine & 100.9 & 97.1 \\
Leucine & 79.1 & 83.7 \\
Lysine & 102.2 & 106.1 \\
Methionine & 97.7 & 100.4 \\
Phenylalanine & 102.7 & 89.4 \\
Proline & 120.6 & 97.3 \\
Serine & 91.3 & 91.3 \\
Threonine & 106.6 & 108.6 \\
Tryptophan & 103.5 & 103.0 \\
Tyrosine & 98.2 & 99.2 \\
Valine & 100.8 & 98.8 \\
\hline
\end{tabular}

calculated level. The recovery (\%) values for each amino acid are shown in Table 4.

The accuracy of the present method (LC-MS/MS) has been compared with that of a HPLC-fluorescence method (LCFLD) with derivatization using $o$-phthalaldehyde (OPA) and 9-fluorenylmethyl chloroformate (FMOC) described in the literature (11) that was previously implemented in the laboratory. However, the comparison was not possible for all amino acids analyzed by LC-MS/MS. This was caused by the fact that the LC-FLD method is less sensitive than the LS-MS/MS method and showed for some amino acids results below detection limit (e.g., for leucine and iso- leucine) or because specific amino acids were not analyzed in the LC-FLD method (e.g., tryptophan and hydroxyproline). The comparison showed that proline and lysine have large differences between the two methods. Proline levels indicated by the LC-MS/MS method were significantly larger (up to $50 \%$ ) than those detected by the LCFLD. Proline having a secondary amine group, does not react with OPA and was detected based on its derivatized form with FMOC. The peak of proline elutes late in the LCFLD separation and its measurement may encounter difficulties. For this reason, the LC-MS/MS procedure was considered to have significantly more reliable results for proline. In the case of lysine, the results for LC-FLD were larger than those obtained by the LC-MS/MS method (with RSD $\%$ of $30 \%-50 \%$ ). Lysine having two amine groups may react differently than other amino acids during derivatization, and its peak in LC-FLD procedure is known to show larger variability than for other amino acids. For the other amino acids where data were available by both methods, the agreement was very good, with RSD\% differences (from the average of results from both methods) being usually less than $10 \%$. An example of comparison between the LC-FLD and LC-MS/MS method for two different tobaccos is illustrated in Table 5.

The limit of quantitation LOQ (and implicitly the limit of detection LOD) were both very different from one amino acid to another. The $\mathrm{S} / \mathrm{N}$ values for the lowest standard $(0.25 \mu \mathrm{mol} / \mathrm{L})$ were shown in Table 3. Considering that the LOQ corresponds to $\mathrm{S} / \mathrm{N} \approx 10$ (see, e.g. (19)), it can be seen that for all amino acids the condition $\mathrm{S} / \mathrm{N}>10$ is fulfilled at $0.25 \mu \mathrm{mol} / \mathrm{L}$ concentration (lowest standard). Some amino acids have a much larger $\mathrm{S} / \mathrm{N}$ values than 10 at this concentration and therefore they can be measured at lower concentrations. In addition, the sample preparation requires a dilution of 1/500 from sample weight to volume of solvent. This dilution factor can be decreased significantly if a better sensitivity is necessary.

Table 5. Example of comparison for the levels of amino acids in $\mathrm{mg} / \mathrm{g}$ between the LC-FLD and LC-MS/MS methods for two different tobaccos.

\begin{tabular}{|c|c|c|c|c|c|c|}
\hline \multirow{2}{*}{ Amino acid } & \multicolumn{2}{|c|}{ Tobacco A (mg/g) } & \multirow{2}{*}{$\begin{array}{c}\text { Difference \% } \\
\text { FLD - MS }\end{array}$} & \multicolumn{2}{|c|}{ Tobacco B $(\mathrm{mg} / \mathrm{g})$} & \multirow{2}{*}{$\begin{array}{c}\text { Difference \% } \\
\text { FLD - MS }\end{array}$} \\
\hline & LC-FLD & LC-MS/MS & & LC-FLD & LC-MS/MS & \\
\hline Alanine & 0.578 & 0.575 & 0.5 & 0.528 & 0.530 & -0.4 \\
\hline Arginine & 0.150 & 0.130 & 14.3 & 0.150 & 0.147 & 2.0 \\
\hline Asparagine & 0.431 & 0.446 & -3.4 & 0.493 & 0.471 & 4.6 \\
\hline Aspartic acid & 4.948 & 4.490 & 9.7 & 9.830 & 8.474 & 14.8 \\
\hline Glutamic acid & 3.996 & 3.732 & 6.8 & 4.223 & 3.972 & 6.1 \\
\hline Glutamine & 0.337 & 0.320 & 5.2 & 0.393 & 0.350 & 11.6 \\
\hline Glycine & 0.130 & 0.142 & -8.8 & 0.156 & 0.165 & -5.6 \\
\hline Histidine & 0.453 & 0.415 & 8.8 & 0.613 & 0.543 & 12.1 \\
\hline Isoleucine & 0.113 & 0.099 & 13.2 & 0.113 & 0.095 & 17.3 \\
\hline Leucine & 0.108 & 0.106 & 1.9 & 0.108 & 0.106 & 1.9 \\
\hline Lysine & 0.724 & 0.427 & 51.6 & 0.725 & 0.448 & 47.2 \\
\hline Methionine & 0.012 & 0.014 & -12.9 & 0.012 & 0.013 & -5.5 \\
\hline Phenylalanine & 0.142 & 0.150 & -5.5 & 0.362 & 0.364 & -0.6 \\
\hline Proline & 3.139 & 5.311 & -51.4 & 1.426 & 2.524 & -55.6 \\
\hline Serine & 0.212 & 0.194 & 8.9 & 0.312 & 0.331 & -5.9 \\
\hline Threonine & 0.099 & 0.087 & 12.9 & 0.122 & 0.116 & 5.0 \\
\hline Tyrosine & 0.056 & 0.051 & 9.3 & 0.055 & 0.049 & 11.5 \\
\hline Valine & 0.100 & 0.094 & 6.2 & 0.139 & 0.137 & 1.4 \\
\hline
\end{tabular}


Table 6. Types of tobacco analyzed in this study.

\begin{tabular}{|c|c|c|c|}
\hline No. & Type $^{a}$ & Year & Description \\
\hline 1 & FC L (1) & 2008 & $\begin{array}{l}\text { Eastern NC belt, lower stalk (lug) } \\
\text { flue-cured }\end{array}$ \\
\hline 2 & $\mathrm{FC} \mathrm{U}(1)$ & 2008 & $\begin{array}{l}\text { Eastern NC belt, upper stalk (leaf \& } \\
\text { some tips) flue-cured }\end{array}$ \\
\hline 3 & $\mathrm{FC} \mathrm{L} \mathrm{(2)}$ & 2009 & $\begin{array}{l}\text { South Carolina belt, lower stalk (lug) } \\
\text { flue-cured }\end{array}$ \\
\hline 4 & $\mathrm{FC} \mathrm{U}(2)$ & 2009 & $\begin{array}{l}\text { South Carolina belt, upper stalk } \\
\text { (leaf \& some tips) flue-cured }\end{array}$ \\
\hline 5 & FC off $L$ & 2006 & $\begin{array}{l}\text { Brazil, lower stalk (lugs \& primings) } \\
\text { flue-cured }\end{array}$ \\
\hline 6 & FC off $U$ & 2006 & $\begin{array}{l}\text { Brazil, upper stalk (leaf \& tips) flue- } \\
\text { cured }\end{array}$ \\
\hline 7 & $\mathrm{Bu} L(1)$ & 2007 & $\begin{array}{l}\text { Kentucky \& Tennessee, lower stalk } \\
\text { (flyings \& cutters) Burley }\end{array}$ \\
\hline 8 & $\mathrm{Bu} \cup(1)$ & 2007 & $\begin{array}{l}\text { Kentucky \& Tennessee, upper stalk } \\
\text { (leaf) Burley }\end{array}$ \\
\hline 9 & $\mathrm{Bu} L(2)$ & 2008 & $\begin{array}{l}\text { North Carolina \& Virginia, lower } \\
\text { stalk (flyings \& cutters) Burley }\end{array}$ \\
\hline 10 & $\mathrm{Bu} \cup(2)$ & 2008 & $\begin{array}{l}\text { North Carolina \& Virginia, upper } \\
\text { stalk (leaf) Burley }\end{array}$ \\
\hline 11 & Bu off $L$ & 2008 & $\begin{array}{l}\text { Malawi, lower stalk (flyings \& } \\
\text { cutters) Burley }\end{array}$ \\
\hline 12 & Bu off U & 2008 & Malawi, upper stalk (leaf) Burley \\
\hline 13 & O Sa U & 2007 & $\begin{array}{l}\text { Turkey, good quality middle to } \\
\text { upper stalk, Samsun Oriental }\end{array}$ \\
\hline & $\mathrm{O}$ lz U & 2005 & $\begin{array}{l}\text { Turkey, good quality middle to } \\
\text { upper stalk, Izmir Oriental }\end{array}$ \\
\hline 15 & $3 R 4 F$ & 2006 & $\begin{array}{l}\text { Tobacco blend from 3R4F Kentucky } \\
\text { reference cigarette }\end{array}$ \\
\hline 16 & Commercial & 2012 & $\begin{array}{l}\text { Common commercial cigarette } \\
\text { blend }\end{array}$ \\
\hline
\end{tabular}

a $\quad F C=$ Flue-cured; $B$ u = Burley; $\mathrm{O}=$ Oriental; $\mathrm{L}=$ Lower stalk; $\mathrm{U}=$ Upper stalk; off $=$ off shore $/$ not USA tobacco

The method robustness evaluation showed that the amino acids solutions (either standards or tobacco extracts) are stable for $24 \mathrm{~h}$ at room temperature. After $48 \mathrm{~h}$ of storage at room temperature, some amino acids (asparagine, glutamine) tended to hydrolyze and displayed lower levels. The HPLC instrument used in this study had a cooling capability for the autosampler, and the sample temperature was set at $10^{\circ} \mathrm{C}$ to improve sample stability. The samples kept in the refrigerator at $2-8{ }^{\circ} \mathrm{C}$ showed less than $10 \%$ variation after 12 days of storage, except for leucine that showed about $16 \%$ variation.

\section{RESULTS AND DISCUSSION}

\section{Types of tobaccos evaluated}

The types of tobaccos analyzed are listed in Table 6 . They include flue-cured and Burley, domestic and off-shore (not USA grown tobaccos), as well as two types of Oriental tobaccos. Tobacco leaf was initially made in cut filler form. Experimental cigarettes containing no humectants or additives were made with each tobacco. The material used for analysis was obtained from the experimental cigarettes kept in the freezer after manufacturing. Also tobacco from a 3R4F cigarette, and one commercial cigarette blend were analyzed.

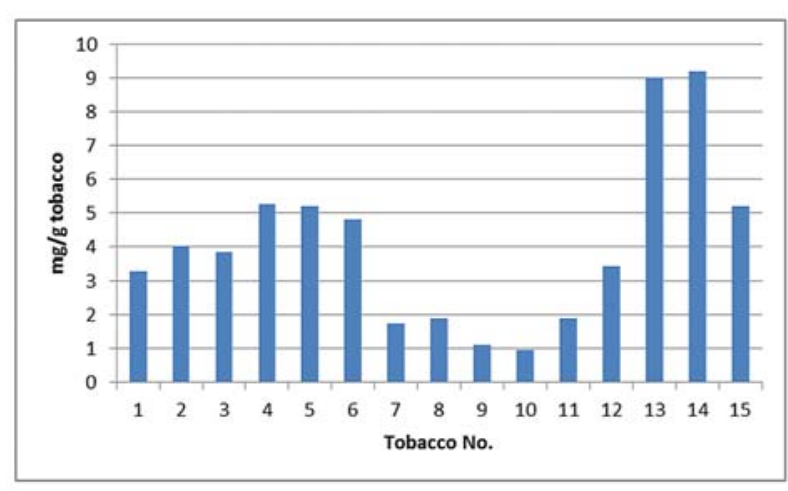

Figure 3. The level of proline $(\mathrm{mg} / \mathrm{g})$ in the analyzed tobacco types. (See Table 6 for tobacco No.)

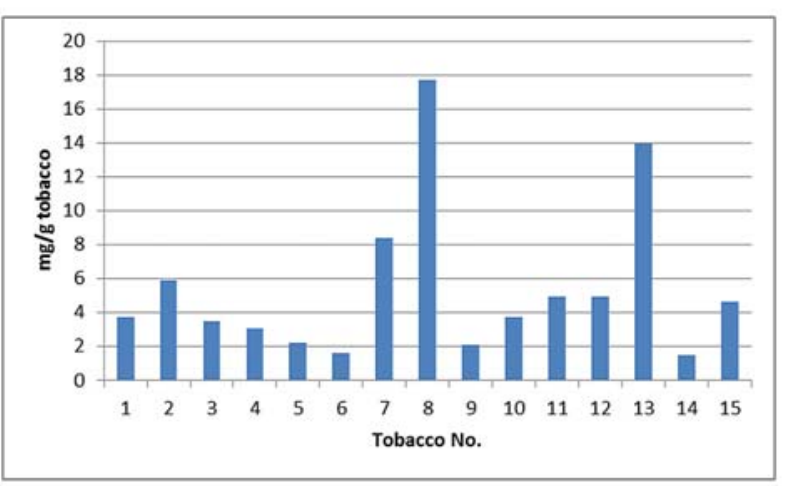

Figure 4. The level of asparagine $(\mathrm{mg} / \mathrm{g})$ in the analyzed tobacco types. (See Table 6 for tobacco No.)

\section{Results of amino acids analysis in tobacco leaf}

The results of LC-MS/MS analysis for 15 tobacco types are given in Table 7. The table indicates the averages of triplicate measurements in $\mathrm{mg} / \mathrm{g}$ of tobacco, and $\mathrm{RSD} \%$ for the measurements. The results from Table 7 show that fluecured tobaccos are characterized by a higher level of proline, while the Burley tobaccos have mainly high levels of asparagine and aspartic acid, in agreement with the information from typical tobacco literature (20). However, a wide range of levels of these amino acids can be seen across various tobaccos. For example, the levels of proline listed in Table 7 show that the largest levels were found in the Oriental tobaccos. Proline levels in the analyzed tobaccos are presented in graph form in Figure 3.

Asparagine levels also vary significantly as a function of tobacco type as shown in Figure 4 (with data from Table 7). This amino acid is of particular interest since it is a precursor for the formation of acrylamide (8) in cigarette smoke. The variation of acrylamide level in smoke (as $\mu \mathrm{g} / \mathrm{mg}$ TPM) (for two smoking regimens: 1) ISO and 2) using $60 \mathrm{~mL}$ puff volume, $2 \mathrm{~s}$ puff, and $30 \mathrm{~s}$ puff interval, no vent blocking, indicated as Intense) as a function of the level of asparagine in tobacco is exemplified in Figure 5 (21). For this reason, the selection of tobaccos low in asparagine is recommended in order to avoid high acrylamide levels in smoke. As shown in Figure 4, asparagine is high in two types of Burley and in Samsun Oriental tobacco as compared to other tobacco types. The levels of aspartic acid $(\mathrm{mg} / \mathrm{g})$ in the analyzed tobacco types are shown in Figure 6. This 
amino acid is high in all Burley tobaccos, relative to other tobacco types.

The data presented in this study is limited to a small set of tobacco samples and a larger set would be necessary for more detailed conclusions. However, even with this limited evaluated set of samples, it can be seen that the level of amino acids between lower stalk (lug) and upper stalk (leaf and some tips) as described in Table 6, differ mainly in the level (with the lower stalk position tobacco having lower levels of amino acids), but not in the amino acid profile.
Also, the study shows that the composition of amino acids in the same type of tobacco (e.g., flue-cured, or Burley) may differ significantly from region to region.

\section{CONCLUSIONS}

A new method using RP-HPLC coupled with MS/MS detection for the analysis of free amino acids in tobacco has been developed. The new method uses separation on an

Table 7. Results of amino acid levels in $\mathrm{mg} / \mathrm{g}$ in the analyzed tobaccos (conditioned as indicated).

\begin{tabular}{|c|c|c|c|c|c|c|c|c|c|}
\hline \multirow{2}{*}{ No. } & \multirow{2}{*}{ Compound } & \multicolumn{2}{|c|}{ Tobacco 1, FC L (1) } & \multicolumn{2}{|c|}{ Tobacco 2, FC U (1) } & \multicolumn{2}{|c|}{ Tobacco 3, FC L (2) } & \multicolumn{2}{|c|}{ Tobacco 4, FC U (2) } \\
\hline & & $\mathrm{mg} / \mathrm{g}$ & RSD\% & $\mathrm{mg} / \mathrm{g}$ & RSD\% & $\mathrm{mg} / \mathrm{g}$ & RSD\% & $\mathrm{mg} / \mathrm{g}$ & RSD\% \\
\hline 1 & Alanine & 0.604 & 2.3 & 0.680 & 2.1 & 0.621 & 2.7 & 0.708 & 1.8 \\
\hline 2 & Arginine & 0.131 & 1.5 & 0.117 & 1.1 & 0.139 & 6.0 & 0.117 & 0.6 \\
\hline 3 & Asparagine & 3.752 & 0.3 & 5.926 & 0.4 & 3.480 & 0.2 & 3.053 & 0.8 \\
\hline 4 & Aspartic acid & 0.955 & 0.2 & 0.919 & 1.3 & 0.881 & 2.6 & 0.683 & 0.3 \\
\hline 5 & Cysteine & 0.009 & 2.6 & 0.012 & 1.9 & 0.011 & 5.2 & 0.013 & 7.1 \\
\hline 6 & Glutamic acid & 0.496 & 0.3 & 0.737 & 0.5 & 0.430 & 0.9 & 0.635 & 0.7 \\
\hline 7 & Glutamine & 0.671 & 0.2 & 1.117 & 0.3 & 0.718 & 0.4 & 0.847 & 0.6 \\
\hline 8 & Glycine & 0.065 & 0.3 & 0.032 & 0.9 & 0.027 & 2.8 & 0.030 & 0.5 \\
\hline 9 & Histidine & 0.213 & 1.6 & 0.286 & 2.6 & 0.178 & 1.7 & 0.193 & 5.2 \\
\hline 10 & Hydroxyproline & 0.004 & 0.9 & 0.002 & 0.7 & 0.001 & 7.2 & 0.002 & 0.0 \\
\hline 11 & Isoleucine & 0.057 & 2.3 & 0.046 & 0.5 & 0.067 & 10.3 & 0.041 & 1.7 \\
\hline 12 & Leucine & 0.051 & 4.8 & 0.044 & 2.7 & 0.055 & 0.2 & 0.059 & 1.8 \\
\hline 13 & Lysine & 0.219 & 0.7 & 0.180 & 0.0 & 0.155 & 0.0 & 0.460 & 0.0 \\
\hline 14 & Methionine & 0.001 & 0.1 & 0.001 & 1.1 & 0.001 & 6.1 & 0.001 & 5.9 \\
\hline 15 & Phenylalanine & 0.140 & 0.8 & 0.214 & 0.5 & 0.257 & 0.4 & 0.115 & 0.6 \\
\hline 16 & Proline & 3.273 & 0.4 & 3.999 & 0.3 & 3.817 & 1.8 & 5.257 & 1.4 \\
\hline 17 & Serine & 0.253 & 0.1 & 0.188 & 0.9 & 0.059 & 4.8 & 0.050 & 4.9 \\
\hline 18 & Threonine & 0.207 & 0.4 & 0.476 & 0.6 & 0.224 & 1.1 & 0.478 & 1.1 \\
\hline 19 & Tryptophan & 0.067 & 2.9 & 0.051 & 2.3 & 0.068 & 1.9 & 0.066 & 0.8 \\
\hline 20 & Tyrosine & 0.120 & 1.7 & 0.124 & 1.2 & 0.133 & 0.7 & 0.076 & 1.1 \\
\hline 21 & Valine & 0.218 & 4.4 & 0.680 & 2.1 & 0.141 & 2.6 & 0.247 & 6.8 \\
\hline \multirow{2}{*}{ No. } & \multirow{2}{*}{ Compound } & \multicolumn{2}{|c|}{ Tobacco 5, FC off L } & \multicolumn{2}{|c|}{ Tobacco 6, FC off U } & \multicolumn{2}{|c|}{ Tobacco 7, Bu L (1) } & \multicolumn{2}{|c|}{ Tobacco 8, Bu U (1) } \\
\hline & & $\mathrm{mg} / \mathrm{g}$ & $\mathrm{RSD} \%$ & $\mathrm{mg} / \mathrm{g}$ & RSD\% & $\mathrm{mg} / \mathrm{g}$ & $\mathrm{RSD} \%$ & $\mathrm{mg} / \mathrm{g}$ & RSD\% \\
\hline 1 & Alanine & 0.526 & 2.2 & 0.474 & 1.4 & 0.637 & 1.6 & 1.389 & 2.0 \\
\hline 2 & Arginine & 0.104 & 1.8 & 0.114 & 2.3 & 0.264 & 5.6 & 0.503 & 4.3 \\
\hline 3 & Asparagine & 2.226 & 0.4 & 1.605 & 0.2 & 8.365 & 0.2 & 17.696 & 1.2 \\
\hline 4 & Aspartic acid & 0.847 & 2.0 & 0.509 & 1.2 & 5.323 & 0.5 & 7.921 & 1.5 \\
\hline 5 & Cysteine & 0.013 & 2.7 & 0.008 & 5.7 & 0.012 & 5.7 & 0.007 & 8.3 \\
\hline 6 & Glutamic acid & 0.727 & 0.4 & 0.325 & 1.2 & 1.615 & 1.0 & 2.070 & 1.4 \\
\hline 7 & Glutamine & 0.667 & 0.4 & 0.147 & 0.1 & 0.103 & 6.4 & 0.184 & 0.4 \\
\hline 8 & Glycine & 0.023 & 3.9 & 0.017 & 0.9 & 0.070 & 0.0 & 0.076 & 0.8 \\
\hline 9 & Histidine & 0.272 & 1.3 & 0.160 & 0.3 & 0.358 & 1.9 & 0.868 & 2.7 \\
\hline 10 & Hydroxyproline & 0.002 & 8.3 & 0.003 & 1.3 & 0.002 & 0.1 & 0.002 & 8.2 \\
\hline 11 & Isoleucine & 0.047 & 1.7 & 0.036 & 0.5 & 0.087 & 5.4 & 0.071 & 3.2 \\
\hline 12 & Leucine & 0.050 & 8.1 & 0.041 & 9.2 & 0.109 & 2.0 & 0.138 & 0.8 \\
\hline 13 & Lysine & 0.398 & 0.4 & 0.251 & 1.7 & 0.699 & 0.0 & 0.548 & 0.1 \\
\hline 14 & Methionine & 0.001 & 1.5 & 0.001 & 1.0 & 0.001 & 2.0 & 0.001 & 5.0 \\
\hline 15 & Phenylalanine & 0.244 & 1.4 & 0.255 & 2.0 & 0.706 & 0.7 & 0.861 & 1.1 \\
\hline 16 & Proline & 5.187 & 1.6 & 4.804 & 1.1 & 1.737 & 1.3 & 1.904 & 0.0 \\
\hline 17 & Serine & 0.163 & 0.2 & 0.029 & 2.1 & 0.075 & 3.5 & 0.118 & 1.1 \\
\hline 18 & Threonine & 0.327 & 0.8 & 0.442 & 0.2 & 0.206 & 1.2 & 0.340 & 2.0 \\
\hline 19 & Tryptophan & 0.070 & 1.7 & 0.031 & 1.2 & 0.134 & 3.4 & 0.285 & 1.7 \\
\hline 20 & Tyrosine & 0.093 & 1.2 & 0.083 & 2.4 & 0.082 & 0.3 & 0.179 & 3.9 \\
\hline 21 & Valine & 0.152 & 4.7 & 0.111 & 5.0 & 0.143 & 6.0 & 0.241 & 1.0 \\
\hline
\end{tabular}

a $\quad \mathrm{FC}=$ Flue-cured; $\mathrm{Bu}=$ Burley; $\mathrm{O}=$ Oriental; $\mathrm{L}=$ Lower stalk; $\mathrm{U}=$ Upper stalk; off = off shore $/$ not USA tobacco 
Table 7. Contd.

\begin{tabular}{|c|c|c|c|c|c|c|c|c|c|}
\hline \multirow{2}{*}{ No. } & \multirow{2}{*}{ Compound } & \multicolumn{2}{|c|}{ Tobacco 9, Bu L (2) } & \multicolumn{2}{|c|}{ Tobacco 10, Bu U (2) } & \multicolumn{2}{|c|}{ Tobacco 11, Bu off L } & \multicolumn{2}{|c|}{ Tobacco 12, Bu off $U$} \\
\hline & & $\mathrm{mg} / \mathrm{g}$ & RSD $\%$ & $\mathrm{mg} / \mathrm{g}$ & RSD $\%$ & $\mathrm{mg} / \mathrm{g}$ & RSD $\%$ & $\mathrm{mg} / \mathrm{g}$ & RSD \% \\
\hline 1 & Alanine & 0.348 & 0.2 & 0.475 & 0.2 & 0.669 & 1.6 & 0.969 & 2.2 \\
\hline 2 & Arginine & 0.223 & 1.8 & 0.339 & 1.2 & 0.189 & 1.0 & 0.242 & 0.7 \\
\hline 3 & Asparagine & 2.098 & 0.3 & 3.755 & 0.7 & 4.916 & 0.8 & 4.923 & 0.6 \\
\hline 4 & Aspartic acid & 4.830 & 1.3 & 10.135 & 0.4 & 8.208 & 0.0 & 7.693 & 0.3 \\
\hline 5 & Cysteine & 0.013 & 10.6 & 0.007 & 8.3 & 0.013 & 8.2 & 0.007 & 3.1 \\
\hline 6 & Glutamic acid & 1.124 & 0.7 & 2.118 & 0.0 & 1.150 & 1.4 & 1.492 & 0.3 \\
\hline 7 & Glutamine & 0.103 & 7.3 & 0.087 & 5.8 & 0.109 & 0.3 & 0.167 & 2.4 \\
\hline 8 & Glycine & 0.058 & 0.4 & 0.070 & 2.7 & 0.061 & 1.5 & 0.062 & 2.1 \\
\hline 9 & Histidine & 0.216 & 0.4 & 0.295 & 0.2 & 0.170 & 0.8 & 0.157 & 2.4 \\
\hline 10 & Hydroxyproline & 0.003 & 2.0 & 0.004 & 1.3 & 0.006 & 1.9 & 0.006 & 2.3 \\
\hline 11 & Isoleucine & 0.097 & 9.5 & 0.053 & 2.5 & 0.050 & 0.0 & 0.062 & 0.2 \\
\hline 12 & Leucine & 0.111 & 0.0 & 0.112 & 0.7 & 0.086 & 1.1 & 0.123 & 0.1 \\
\hline 13 & Lysine & 0.411 & 0.2 & 0.473 & 0.9 & 0.462 & 0.5 & 0.440 & 0.0 \\
\hline 14 & Methionine & 0.001 & 5.3 & 0.001 & 2.9 & 0.001 & 2.7 & 0.001 & 3.3 \\
\hline 15 & Phenylalanine & 0.325 & 0.1 & 0.558 & 0.9 & 0.542 & 0.4 & 0.559 & 0.9 \\
\hline 16 & Proline & 1.115 & 0.0 & 0.958 & 1.2 & 1.892 & 1.4 & 3.425 & 2.2 \\
\hline 17 & Serine & 0.123 & 0.8 & 0.175 & 0.4 & 0.255 & 0.0 & 0.318 & 0.6 \\
\hline 18 & Threonine & 0.257 & 1.3 & 0.283 & 1.4 & 0.342 & 1.2 & 0.415 & 2.0 \\
\hline 19 & Tryptophan & 0.100 & 1.3 & 0.131 & 0.1 & 0.104 & 1.2 & 0.083 & 3.3 \\
\hline 20 & Tyrosine & 0.065 & 9.1 & 0.073 & 3.1 & 0.092 & 1.5 & 0.095 & 3.0 \\
\hline 21 & Valine & 0.141 & 1.3 & 0.134 & 1.0 & 0.174 & 3.0 & 0.308 & 2.8 \\
\hline \multirow{2}{*}{ No. } & \multirow{2}{*}{ Compound } & \multicolumn{2}{|c|}{ Tobacco $13, \mathrm{O}$ Sa U } & \multicolumn{2}{|c|}{ Tobacco 14, O Iz U } & \multicolumn{2}{|c|}{ Tobacco 15, 3R4F } & \multicolumn{2}{|c|}{ Tobacco 16, Commer } \\
\hline & & $\mathrm{mg} / \mathrm{g}$ & $\mathrm{RSD} \%$ & $\mathrm{mg} / \mathrm{g}$ & $\mathrm{RSD} \%$ & $\mathrm{mg} / \mathrm{g}$ & $\mathrm{RSD} \%$ & $\mathrm{mg} / \mathrm{g}$ & $\mathrm{RSD} \%$ \\
\hline 1 & Alanine & 1.494 & 2.9 & 0.868 & 1.4 & 0.308 & 2.0 & 0.712 & 1.9 \\
\hline 2 & Arginine & 0.260 & 3.0 & 0.125 & 1.0 & 0.253 & 2.8 & 0.124 & 3.2 \\
\hline 3 & Asparagine & 13.934 & 0.6 & 1.461 & 0.5 & 2.626 & 3.4 & 4.641 & 0.2 \\
\hline 4 & Aspartic acid & 3.499 & 0.3 & 0.324 & 1.7 & 2.538 & 2.1 & 2.513 & 0.1 \\
\hline 5 & Cysteine & 0.013 & 7.7 & 0.007 & 0.0 & 0.004 & 6.1 & 0.007 & 5.0 \\
\hline 6 & Glutamic acid & 1.798 & 1.4 & 0.303 & 0.8 & 1.341 & 1.7 & 0.898 & 1.3 \\
\hline 7 & Glutamine & 2.854 & 0.1 & 0.494 & 0.1 & 2.304 & 1.7 & 0.564 & 0.4 \\
\hline 8 & Glycine & 0.070 & 2.3 & 0.018 & 0.3 & 0.122 & 3.6 & 0.037 & 3.6 \\
\hline 9 & Histidine & 0.627 & 0.9 & 0.095 & 3.5 & 0.660 & 1.1 & 0.192 & 0.5 \\
\hline 10 & Hydroxyproline & 0.004 & 5.5 & 0.003 & 0.6 & 0.002 & 2.1 & 0.002 & 5.9 \\
\hline 11 & Isoleucine & 0.063 & 3.8 & 0.048 & 0.9 & 0.027 & 1.4 & 0.057 & 1.0 \\
\hline 12 & Leucine & 0.112 & 2.4 & 0.053 & 2.8 & 0.040 & 2.3 & 0.066 & 5.7 \\
\hline 13 & Lysine & 0.319 & 0.1 & 0.475 & 0.1 & 0.485 & 5.3 & 0.345 & 0.0 \\
\hline 14 & Methionine & 0.001 & 1.7 & 0.001 & 3.3 & 0.001 & 3.1 & 0.001 & 3.3 \\
\hline 15 & Phenylalanine & 0.970 & 0.4 & 0.236 & 1.1 & 0.175 & 0.8 & 0.552 & 0.1 \\
\hline 16 & Proline & 9.002 & 1.4 & 9.194 & 1.2 & 3.138 & 6.1 & 5.205 & 0.1 \\
\hline 17 & Serine & 0.386 & 0.1 & 0.027 & 2.0 & 0.458 & 2.5 & 0.173 & 0.0 \\
\hline 18 & Threonine & 0.323 & 0.6 & 0.080 & 2.3 & 0.593 & 1.7 & 0.212 & 0.7 \\
\hline 19 & Tryptophan & 0.195 & 1.3 & 0.036 & 2.7 & 0.049 & 1.1 & 0.063 & 2.0 \\
\hline 20 & Tyrosine & 0.175 & 2.4 & 0.067 & 2.1 & 0.166 & 2.2 & 0.100 & 0.7 \\
\hline 21 & Valine & 0.227 & 1.0 & 0.130 & 3.8 & 0.088 & 3.1 & 0.135 & 5.8 \\
\hline
\end{tabular}

a $\quad F C=$ Flue-cured; $B u=$ Burley; $\mathrm{O}=$ Oriental; $\mathrm{L}=$ Lower stalk; $\mathrm{U}=$ Upper stalk; off $=$ off shore $/$ not USA tobacco

Acclaim $^{\mathrm{TM}}$ RSLC Polar Advantage II column, with gradient separation of amino acids. The accuracy of the new method compares well with a HPLC-fluorescence with derivatization method, previously utilized for amino acids analysis, but has a lower limit of quantitation allowing the measurement of amino acids not possible to analyze by the fluorescence method. The method offers a number of advantages such as no need for derivatization, excellent peak shape in the chromatogram, good separation, and positive identification of each amino acid in the tobacco matrix.

\section{REFERENCES}

1. Weeks, W.W.: Relationship Between Leaf Chemistry and Organoleptic Properties of Tobacco Smoke; in: Tobacco, Production, Chemistry and Technology, edited by D.L. Davis and M.T. Nielsen, Blackwell Science, Oxford, UK, 1999.

2. Collins, P.F., N.M. Sarji, and J.F. Williams: An Automated Procedure for the Determination of Total Amino Acids and its Application to the Analysis of Tobacco; Beitr. Tabakforsch.. 7 (1974) 228-234. 


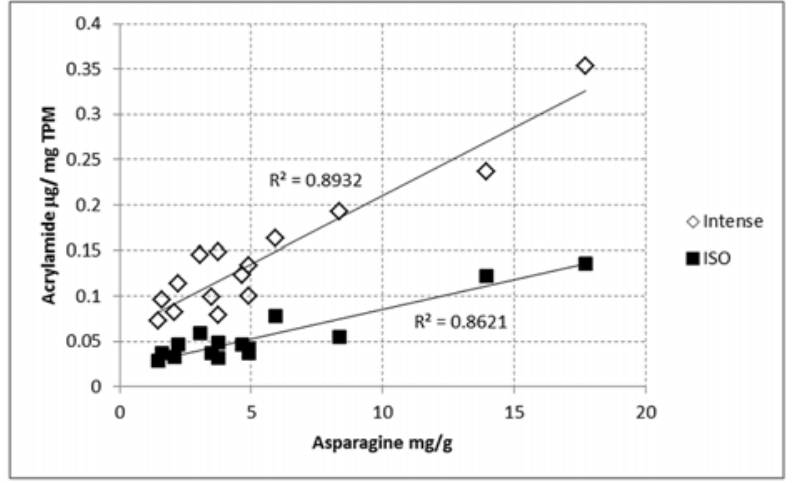

Figure 5. Variation of the level of acrylamide in cigarette smoke (in $\mu \mathrm{g} / \mathrm{mg}$ TPM), as a function of asparagine level in tobacco $(\mathrm{mg} / \mathrm{g})$.

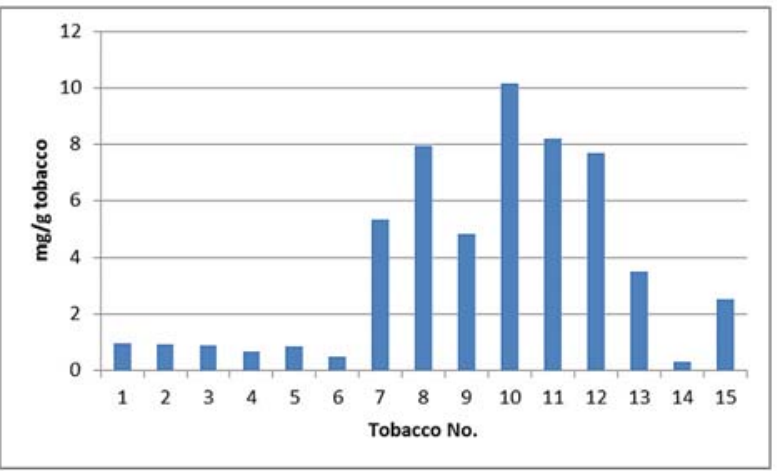

Figure 6. The level of aspartic acid $(\mathrm{mg} / \mathrm{g})$ in the analyzed tobacco types. (See Table 6 for tobacco No.)

3. Peng, L., M. Wu, and J. Xie: Changes in Levels of Amino Acids and Basic Components in Burley Tobacco Produced by Roasting; Beitr. Tabakforsch. Int. 20 (2003) 459-466.

4. Préfontaine, D., A. Morin, C. Jumarie, and A. Porter: In Vitro Bioactivity of Combustion Products From 12 Tobacco Constituents; Food Chem. Toxicol. 44 (2006) 724-738.

5. Mizusaki, S., H. Okamoto, A. Akiyama, and Y. Fukuhara: Relation Between Chemical Constituents of Tobacco and Mutagenic Activity of Cigarette Smoke Condensate; Mutat. Res. 48 (1977) 319-325.

6. Moldoveanu, S.C.: Pyrolysis of Organic Molecules with Applications to Health and Environmental Issues; Elsevier, Amsterdam, The Netherlands, 2010.

7. Moldoveanu, S.C. and A.R. Gerardi: Acrylamide Analysis in Tobacco, Alternative Tobacco Products, and Cigarette Smoke; J. Chromatogr. Sci. 49 (2011) 234-242.

8. Amrein, T.M.: Systematic Studies on Process Optimization to Minimize Acrylamide Contents in Food; Diss. ETH Nr. 16311, Zurich, Switzerland, 2005.

9. Carugno, N., M. Neri, and G. Lionetti: Quantitative Determination of Free and Protein-Bound Amino Acids of Tobacco; Beitr. Tabakforsch. 7 (1974) 222-227.
10. Zhu, X.-L., Q.-S. Zhu, and Y. Gao: Fast Analysis of Free Amino Acids in Tobacco by HPLC with Fluorescence Detection and Automated Derivatization; J. Chin. Chem. Soc. 55 (2008) 1094-1100.

11. Henderson, J.W., R.D. Ricker, B.A. Bidlingmeyer, and C. Woodward: Rapid, Accurate, Sensitive, and Reproducible HPLC Analysis of Amino Acids; Agilent Technologies, USA, Part No. 5980-1193E.

12. Özcan, S. and H. Z. Senyuva: Improved and Simplified Liquid Chromatography / Atmospheric Pressure Chemical Ionization Mass Spectrometry Method for the Analysis of Underivatized Free Amino Acids in Various Foods; J. Chromatogr. A 1135 (2006) 179-185.

13. Moldoveanu, S.C.: Analysis of Protein Amino Acids in Tobacco Using Microwave Digestion of Plant Material; Beitr. Tabakforsch. Int. 21 (2005) 451-465.

14. Henderson Jr, J.W. and A. Brooks: Improved Amino Acid Methods Using Agilent ZORBAX Eclipse Plus C18 Columns for A Variety of Agilent LC Instrumentation and Separation Goals; Agilent Technologies, USA, Part No. 5990-4547EN.

15. Woodward, C., J.W. Henderson, and T. Wielgos: Highspeed Amino Acid Analysis (AAA) on $1.8 \mu \mathrm{M}$ Reversed-phase (RP) Columns; Agilent Technologies, USA, Part No. 5989-6297EN, 2007.

16. Gritti, F.: Quantification of Individual Mass Transfer Phenomena in Liquid Chromatography for Further Improvement of Column Efficiency; LC/GC North America, 32 (2014) 928-940.

17. Gritti, F. and G. Guiochon: Comparison Between the Intra-Particle Diffusivity in the Hydrophilic Interaction Chromatography and Reversed Phase Liquid Chromatography Modes. Impact on the Column Efficiency; J. Chromatogr. A 1297 (2013) 85-95.

18. Moldoveanu, S. and V. David: Modern Sample Preparation for Chromatography; Elsevier, Amsterdam, The Netherlands, 2014.

19. Moldoveanu, S.C. and V. David: Essentials in Modern HPLC Separations, Elsevier, Amsterdam, The Netherlands, 2013.

20. Leffingwell, J.C.: Leaf Chemistry; in: Tobacco: Production, Chemistry and Technology, edited by D.L. Davis and M.T. Nielsen, Blackwell Science, Oxford, UK, 1999, pp.265-312.

21. Elliott, P.E., D.M. Lawson, and S.C. Moldoveanu: Tobacco Having Reduced Amounts of Amino Acids and Methods for Producing Such Lines; Patent application number: 20130068240, Publication date: 2013-03-21.

\section{Corresponding author:}

Serban C. Moldoveanu

R.J. Reynolds Tobacco Co.

Winston-Salem NC, USA

E-mail:MoldovS@RJRT.com 